\title{
HUBUNGAN KEBIASAAN MANDI DI SUNGAI DENGAN INFEKSI SALURAN KEMIH PADA ANAK DI KELURAHAN SINDULANG 1
}

\author{
${ }^{1}$ Chensilya Kusumanarwasti \\ ${ }^{2}$ Adrian Umboh \\ ${ }^{3}$ Johnny Rompis \\ Bagian Ilmu Kesehatan Anak Universitas Sam Ratulangi \\ chensilya@gmail.com
}

\begin{abstract}
Abstrak: Infeksi saluran kemih (ISK) pada anak merupakan salah satu masalah kesehatan yang paling sering terjadi, dengan angka kejadian yang hanya sedikit lebih rendah dibandingkan ISPA dan infeksi digestif. Salah satu keadaan penting yang perlu diperhatikan pada gejala ISK adalah bakteriuria. Bakteriuria adalah suatu keadaan dimana bakteri dapat ditemukan didalam urin, tetapi keadaan ini tidak selalu berarti ISK. Bakteri gram negatif, khususnya Eschericia coli merupakan penyebab utama ISK (85-90\%). Survei awal yang dilakukan peneliti di kelurahan Sindulang 1, kecamatan Tuminting, kota Manado, menduga bahwa sungai Tondano di daerah tersebut tercemar E.coli.

Penelitian ini merupakan penelitian analitik observasional dengan pendekatan potong lintang (cross sectional). Penelitian dilakukan di kelurahan Sindulang 1, kecamatan Tuminting, kota Manado, selama bulan November sampai Desember 2012, dengan sampel adalah 60 anak yang berusia antara 5-12 tahun.

Hasil penelitian yang diperoleh, terdapat 39 orang anak yang memiliki kebiasaan mandi di sungai dan 21 orang anak tidak memiliki kebiasaan mandi disungai. 39 orang yang mandi di sungai, didapatkan 2 orang anak yang positif menderita ISK. Hasil statistik menunjukan bahwa terdapat hubungan yang bermakna antara mandi di sungai dengan kejadian ISK.
\end{abstract}

Kata kunci: kebiasaan mandi di sungai, ISK, urinalisis

Abstract: Urinary tract infections (UTI) in children is one of the most common health problems, the incidence is only slightly lower than the respiratory and digestive infections. One of the most important conditions that need attention from some symptoms of UTI is bacteriuria. Bacteriuria is a condition in which bacteria can be found in the urine, but this situation does not always mean UTI. Gram-negative bacteria, especially Escherichia coli is the leading cause of UTI (85-90\%). Preliminary survey conducted by researchers at the Sindulang 1 village, of the Tuminting district, of the city of Manado, suspect that the Tondano river is polluted by E.coli.

This was an observational analytic study with cross-sectional approach. The study was conducted in the Sindulang 1 village, of the Tuminting district, of the city of Manado, during November and December 2012, the sample was 60 children aged between 5-12 years.

The results obtained, there are 39 childrens who have a river bathing habit and 21 child doesn't. 39 people who bathe in the river, got 2 children who were positive for UTI. Subjects suffering from UTI confirmed by performing urinalysis, where meaningful results if leukocytes is $\geq 5 \mathrm{WBC} / \mathrm{hpf}$. From the statistical showed that there is a significant relationship between bathing in the river with the incidence of UTI.

Keywords: river bathing habits, UTI, urinalysis

\section{PENDAHULUAN}

Infeksi saluran kemih (ISK) pada anak merupakan salah satu masalah kesehatan yang paling sering terjadi, dengan angka kejadian yang hanya sedikit lebih rendah dibandingkan ISPA dan infeksi digestif. ${ }^{1}$

Angka kejadian ISK tergantung usia dan jenis kelamin. Pada usia awal kehidupan, khususnya pada 3 bulan pertama, ISK lebih umum pada anak laki-laki $(3,7 \%)$ dibandingkan anak perempuan (2\%). Setelah itu, angka insidensi berubah menjadi $3 \%$ pada anak perempuan dan $1,1 \%$ pada anak laki-laki. ${ }^{1-5}$ 
Salah satu keadaan penting yang perlu diperhatikan pada gejala ISK adalah bakteriuria. Bakteriuria adalah suatu keadaan dimana bakteri dapat ditemukan didalam urine, tetapi keadaan ini tidak selalu berarti ISK. Bakteriuria seringkali bersifat asimptomatik. Bakteriuria seringkali dikenal dengan istilah lain yaitu pyuria, yang berarti keadaan dimana ditemukan leukosit pada urine. Leukosit dalam urine merupakan tanda bahwa adanya respon inflamasi akibat infeksi bakteri. ${ }^{4,5}$

Bakteri gram negatif, khususnya Eschericia coli merupakan penyebab utama ISK (85-90\%). ${ }^{1,2,5}$ Walaupun merupakan flora normal dalam tubuh (khususnya usus besar), E. coli sering juga di temukan di alam bebas (air atau tanah yang tercemar kotoran manusia). ${ }^{6}$ Bakteriuria dapat terjadi jika bakteri penyebab masuk ke saluran kemih. ${ }^{1,2}$

Survei awal yang dilakukan peneliti di kelurahan Sindulang 1, kecamatan Tuminting, kota Manado, diduga bahwa sungai Tondano di daerah tersebut tercemar E. coli. Penulis juga melihat bahwa anak-anak di daerah tersebut masih memanfaatkan air sungai untuk mandi atau bermainmain. Jika demikian, sangat mungkin anak-anak tersebut ada yang mengalami bakteriuria. Untuk membuktikannya, perlu dilakukan urinalisis pada anak-anak yang memiliki kebiasaan mandi di sungai. ${ }^{1,2,7}$

Penelitian ini bertujuan untuk: tujuan umum mengetahui hubungan antara kebiasaan mandi di sungai dengan ISK pada anak. Tujuan khusus untuk mengetahui hubungan antara kebiasaan mandi di sungai dengan ISK pada anak di kelurahan Sindulang 1, berdasarkan temuan leukosit dalam jumlah tertentu pada hasil pemeriksaan urinalisis.

\section{METODE PENELITIAN}

Penelitian ini merupakan penelitian analitik observasional dengan pendekatan potong lintang (cross sectional). ${ }^{8}{ }^{9}$ Penelitian dilakukan di kelurahan Sindulang 1, kecamatan Tuminting, kota Manado selama bulan November sampai Desember 2012. Populasi dalam penelitian ini ialah semua anak yang tinggal di kelurahan Sindulang 1 dan memiliki kebiasaan mandi di sungai setiap hari dan memenuhi kriteria inklusi dan eksklusi. Kriteria inklusi yaitu masyarakat kelurahan Sindulang 1, terdaftar dan menetap, anak-anak, berusia 5-12 tahun, memiliki kebiasaan mandi di sungai setiap hari, bersedia dengan sukarela untuk dijadikan sebagai subjek penelitian dan bersikap kooperatif selama penelitian. Perhitungan besar sampel yang dibutuhkan dalam penelitian ini diperoleh dengan menggunakan rumus: ${ }^{6}$

$$
\begin{aligned}
& \qquad N=\left\{\frac{Z \alpha-Z \beta}{\left\{0,5 \ln \left[\frac{(1+r)}{(1-r)}\right]\right\}}\right\}^{2}+3 \\
& \text { Keterangan: } \\
& \mathrm{N}=\text { perkiraan besar sampel kasus } \\
& \mathrm{Z} \alpha=\text { deviat baku alpha }=5 \% \text {, maka } \mathrm{Z} \alpha=1,64 \\
& \mathrm{Z} \beta=\text { deviat baku beta }=20 \% \text {, maka } \mathrm{Z} \beta=0,84 \\
& \mathrm{r}=\text { koefisien korelasi }=0,40 \\
& \text { ln = logaritma natural } \\
& \text { Dalam penelitian ini dengan nilai-nilai di atas diperoleh } \mathrm{N}=60
\end{aligned}
$$

Variabel bebas dalam penelitian ini yaitu kebiasaan mandi di sungai, dan variabel tergantung dalam penelitian ini yaitu infeksi saluran kemih (ISK). Definisi operasional dalam panelitian ini yaitu kebiasaan mandi di sungai yang dimaksud adalah kebiasaan anak-anak yang memanfaatkan air sungai untuk keperluan mandi dengan intensitas setiap hari dalam hal ini anak-anak tersebut berendam diri di sungai, ISK adalah suatu keadaan ditemukannya bakteri di dalam urine yang menyebabkan infeksi. Keadaan ini dibuktikan dari adanya leukosit dalam jumlah tertentu dari hasil pemeriksaan urinalisis, urinalisis adalah serangkaian tes untuk mengkonfirmasi apakah subjek penelitian mengalami bakteriuria atau tidak. Urinalisis diawali dengan mengumpulkan sampel urine yang dilakukan dengan cara menampung urine ke dalam wadah yang sudah dipersiapkan sebelumnya. Sampel yang diperoleh lalu dibawa ke laboratorium untuk diperiksa. ${ }^{7}$ Yang ditemukan dalam pemeriksaan urinalisis adalah sel darah putih. Bermakna jika ditemukan leukosit sebanyak $\geq 5$ WBC/hpf (high power field) pada sampel yang di-sentrifus atau sebanyak $\geq 10 \mathrm{WBC} / \mathrm{mm}^{3}$ pada 
sampel yang tidak di sentrifus. ${ }^{10,11,12}$ Data diolah dengan uji analisa fisher dengan menggunakan program SPSS versi 21 dengan tingkat kemaknaan $\mathrm{p}<0,01$.

\section{HASIL PENELITIAN}

Berdasarkan hasil penelititian yang dilakukan di kelurahan Sindulang 1, diperoleh data-data yang dapat dilihat pada tabel-tabel di bawah ini:

Tabel 1. Distribusi kejadian ISK berdasarkan jenis kelamin

\begin{tabular}{ccccccc}
\hline \multirow{2}{*}{ Jenis Kelamin } & \multicolumn{2}{c}{ ISK Negatif } & \multicolumn{2}{c}{ ISK Positif } & \multicolumn{2}{c}{ Total } \\
\cline { 2 - 7 } & $\mathrm{n}$ & $\%$ & $\mathrm{n}$ & $\%$ & $\mathrm{n}$ & $\%$ \\
\hline Laki-laki & 41 & 83,7 & 4 & 36,4 & 45 & 75 \\
Perempuan & 8 & 16,8 & 7 & 63,6 & 15 & 25 \\
\hline Total & 49 & 100 & 11 & 100 & 60 & 100 \\
\hline
\end{tabular}

Tabel 2. Distribusi ISK berdasarkan kebiasaan mandi di sungai

\begin{tabular}{ccccccc}
\hline \multirow{2}{*}{ Mandi } & \multicolumn{2}{c}{ ISK Negatif } & \multicolumn{2}{c}{ ISK Positif } & \multicolumn{2}{c}{ Total } \\
\cline { 2 - 7 } & $\mathrm{n}$ & $\%$ & $\mathrm{n}$ & $\%$ & $\mathrm{n}$ & $\%$ \\
\hline Ya & 37 & 75,5 & 2 & 18,2 & 39 & 65,0 \\
Tidak & 12 & 24,5 & 9 & 81,8 & 21 & 35,0 \\
\hline Total & 49 & 100,0 & 11 & 100,0 & 60 & 100,0 \\
\hline
\end{tabular}

Tabel 3. Distribusi ISK berdasarkan intensitas mandi di sungai

\begin{tabular}{ccccccc}
\hline \multirow{2}{*}{ Intensitas (hari) } & \multicolumn{2}{l}{ ISK Negatif } & \multicolumn{2}{l}{ ISK Positif } & \multicolumn{2}{c}{ Total } \\
\cline { 2 - 7 } & $\mathrm{n}$ & $\%$ & $\mathrm{n}$ & $\%$ & $\mathrm{n}$ & $\%$ \\
\hline 0 & 12 & 24,5 & 9 & 81,8 & 21 & 35,0 \\
$1-2$ & 4 & 8,2 & 0 & 0,0 & 4 & 6,7 \\
$3-4$ & 7 & 14,3 & 0 & 0,0 & 7 & 11,7 \\
$5-6$ & 4 & 8,2 & 0 & 0,0 & 4 & 6,7 \\
7 & 22 & 44,9 & 2 & 18,2 & 24 & 40,0 \\
\hline Total & 49 & 100,0 & 11 & 100,0 & 60 & 100,0 \\
\hline
\end{tabular}


Tabel 4. Distribusi ISK berdasarkan durasi mandi di sungai

\begin{tabular}{ccccccc}
\hline \multirow{2}{*}{ Durasi (jam) } & \multicolumn{2}{c}{ ISK Negatif } & \multicolumn{2}{c}{ ISK Positif } & \multicolumn{2}{c}{ Total } \\
\cline { 2 - 7 } & $\mathrm{n}$ & $\%$ & $\mathrm{n}$ & $\%$ & $\mathrm{n}$ & $\%$ \\
\hline 0 & 12 & 24,5 & 9 & 81,8 & 21 & 35,0 \\
$<1$ & 8 & 16,3 & 0 & 0,0 & 8 & 13,3 \\
$>1$ & 29 & 59,2 & 2 & 18,2 & 31 & 51,7 \\
\hline Total & 49 & 100,0 & 11 & 100,0 & 60 & 100,0 \\
\hline
\end{tabular}

\section{PEMBAHASAN}

Hasil penelitian yang dilakukan pada 60 orang anak yang berumur antara 5-12 tahun di Kelurahan Sindulang 1 diketahui bahwa terdapat 45 orang yang berjenis kelamin laki-laki dan 15 orang yang berjenis kelamin perempuan. Dari jumlah tersebut diketahui bahwa yang positif menderita infeksi saluran kemih (ISK) berdasarkan jenis kelamin, perempuan 63,6\% dengan jumlah 7 orang, sedangkan laki-laki 36,4\% dengan jumlah 4 orang. Dari data ini didapatkan bahwa persentase kejadian ISK pada perempuan lebih tinggi dibandingkan dengan pada laki-laki. Ini sesuai dengan teori yang mengatakan bahwa setelah usia 3 bulan pertama, angka insidensi ISK pada anak perempuan lebih besar dari pada anak laki-laki. ${ }^{1-5,6}$ Peneliti menduga rendahnya angka kejadian ISK pada anak laki-laki karena sebagian besar dari mereka telah disirkumsisi. ${ }^{5}$

Dari 60 orang anak sampel, diketahui juga bahwa yang memiliki kebiasaan mandi di sungai berjumlah 39 orang yang tidak memiliki kebiasaan mandi di sungai berjumlah 21 orang. Dari 39 orang yang mandi di sungai didapatkan 2 orang yang positif terkena ISK, dan dari 21 orang yang tidak mandi di sungai didapatkan 9 orang yang positif terkena ISK. Hasil ini berdasarkan perhitungan jumlah leukosit dalam urin ( $>5 \mathrm{WBC} / \mathrm{hpf}){ }^{10,11,12}$

Hasil dari kuesioner yang didapatkan, anak yang mempunyai kebiasaan mandi di sungai yang positif menderita ISK, memiliki intensitas mandi setiap hari dan dengan durasi waktu mandi lebih dari 1 jam. Ini sesuai dengan teori yang mengemukakan bahwa sel uroepitel pada anak sangat rentan terhadap infeksi karena memiliki kapasitas untuk mengikat bakteri, sehingga semakin sering terpapar dengan bakteri penyebab ISK, maka semakin besar pula kesempatan untuk terinfeksi. ${ }^{5}$ Hasil uji Fisher Exact diperoleh nilai $\mathrm{p}=0,001$. Hasil ini menyatakan ada hubungan yang bermakna antara mandi di sungai dengan kejadian ISK ( $p=0,001<$ $\alpha=0,01$ ), namun hasil ini tidak sejalan dengan keadaan sesungguhnya, dimana kemungkinan yang menderita ISK pada anak-anak yang mandi di sungai tidak sepenuhnya disebabkan karena mandi di sungai. Berdasarkan hasil pengamatan peneliti selama berada di lokasi penelitian, kurangnya kesadaran masyarakat akan sanitasi diri dan lingkungan merupakan salah satu penyebab dari ISK, masyarakat masih memiliki kebiasaan membuang kotoran di sungai, pada sebagian masyarakat tidak memiliki toilet, sehingga harus buang air besar di sungai.

Berdasarkan hasil pengujian statistik diperoleh jumlah anak yang tidak memiliki kebiasaan mandi di sungai memiliki angka kejadian ISK lebih tinggi dari pada anak yang mandi di sungai, yaitu 9 orang $(81,8 \%)$. Kemungkinan besar anak-anak yang menderita ISK disebabkan oleh faktor-faktor lain selain mandi di sungai.

Faktor-farktor tersebut seperti : ${ }^{3,5,12,13}$ 
1) Enuresis. Seperti hasil penelitian dari Moh.Noer pada tahun 2006 bahwa $45 \%$ perempuan dengan bakteriuria timbul enuresis dan $15 \%$ anak sekolah dengan bekteriuria mengalami enuresis.

2) Sanitasi alat kelamin yang kurang baik, seperti cara cebok yang salah, tidak membilas perineum dengan air bersih setelah buang air kecil. Saat BAB atau BAK ada kotoran atau bakteri yang ikut dikeluarkan, jika daerah sekitar kelamin tidak dibersihkan maka bakteri tersebut akan masuk ke dalam saluran kemih, sehingga terjadilah infeksi.

3) Kebiasaan menahan air kemih. Air kemih mengandung limbah, kotoran dan racun, jika tertahan di dalam kandung kemih, maka kotoran yang seharusnya dibuang keluar tubuh akan naik ke saluran kemih dan bahkan dapat masuk ke dalam ginjal.

4) Sanitasi air untuk mandi dan kakus yang digunakan

5) Imunodefisiensi

6) Faktor anatomi :

a) Refluks vesiko ureter dan refluks intrarenal

b) Obstruksi saluran kemih

c) Benda asing dalam saluran kemih (kateter urin)

d) Duplikasi collecting system

e) Ureterokel

f) Diventrikulum kandung kemih

\section{SIMPULAN}

Terdapat hubungan antara kebiasaan mandi di sungai dengan infeksi saluran kemih (ISK) di Kelurahan Sindulang 1, namun tidak sejalan dengan keadaan yang sebenarnya, dimana kemungkinan yang terkena ISK pada yang mandi di sungai tidak sepenuhnya karena mandi di sungai.

Temuan dalam penelitian di Kelurahan Sindulang 1 menunjukan bahwa, jumlah anak yang menderita ISK lebih banyak terjadi pada anak-anak yang tidak memiliki kebiasaan mandi di sungai dibandingkan dengan anak-anak yang mandi di sungai.

\section{SARAN}

Bagi institusi kesehatan agar makin mengupayakan usaha peningkatan kesehatan anak di Kelurahan Sindulang 1, perlu ditingkatkan penyuluhan dan sosialisasi kesehatan khususnya tentang penggunaan air bersih dan santitasi diri dan lingkungan.

Bagi pemerintah, perlu ditingkatkan pasokan air bersih, kamar mandi umum dan toilet umum.

Bagi peneliti yang ingin melanjutkan penelitian ini, disarankan dapat mencari faktor-faktor penyebab ISK lainnya dan menambah jumlah sampel.

\section{UCAPAN TERIMA KASIH}

Terima kasih ditujukan kepada:

1) dr. Suryadi N.N. Tatura, SpA (K) sebagai Dosen Penguji I.

2) dr. Rocky Wilar, SpA (K) sebagai Dosen Penguji II.

3) Semua pihak yang secara langsung maupun tidak langsung yang telah memberikan ide/gagasan dalam penulisan skripsi ini. 


\section{DAFTAR PUSTAKA}

1. Grabe M, Bjerklund-Johansen TE, Botto H, Cek M, Naber P, Tenke P, et.al. Urinary Tract Infections in Children. In: Grabe M, Bjerklund-Johansen TE, Botto H, Cek M, Naber P, Tenke P, et.al. Guidelines on Urological Infections. Barcelona: European Association of Urology. 2010; p. 34-44.

2. Gonzales R. Infeksi Saluran Kemih. Dalam: Nelson WE, Kliegman R, Arvin AM. Wahab AS [editor penerjemah]. Ilmu Kesehatan Anak Nelson, ed. 15, vol. 3. Jakarta: Penerbit Buku Kedokteran EGC. 2000; h. 1863-8.

3. Montini G, Tullus K, Hewitt I. Febrile Urinary Tract Infections in Children. The New England Journal of Medicine. 2011; 365-3.

4. Freedman LA. Urinary Tract Infection in Children. In: Freedman LA. Urologic Disease in America. California: National Institute of Health. 2007; p. 441-57.

5. Rusdidjas, Ramayati R. Infeksi Saluran Kemih. Dalam: Alatas H, Tambunan T, Trihono PP, Pardede SO, editor. Buku Ajar Nefrologi Anak ed. 2. Jakarta: Fakultas Kedokteran Universitas Indonesia. 2009; h. 142-63.

6. Gillespie S, Bamford K. Tinia S [alih bahasa]. Patogenisitas Bakteri Gram-negatif Enterik \& Infeksi Saluran Kemih dan Genitalia. Dalam: Gillespie S, Bamford K. Tinia S [alih bahasa]. At a Glance Mikrobiologi Medis dan Infeksi ed. 3. Jakarta: Penerbit Erlangga. 2008; h. 50-1; 104-5.

7. Sacher AR, McPherson AR. Pendit UB [alih bahasa]. Penilaian Laboratorium Cairan Tubuh. Dalam: Sacher AR, McPherson AR. Pendit UB [alih bahasa]. Tinjauan Klinis Hasil Pemeriksaan Laboratorium ed. 11. Jakarta: Penerbit Buku Kedokteran EGC. 2004; 589-614.

8. Madiyono B, Moeslichan S, Sastroasmoro S, Budiman I, Purwanto SH. Perkiraan Besar Sampel. Dalam: Sastroasmoro S, Ismael S. Dasar-dasar Metodologi Penelitian Klinis ed. 4. Jakarta: CV Sagung Seto. 2011; h. 348-81.

9. Nasir A, Muhith A, Ideputri ME. Populasi, Sampel, dan Tehnik Sampling. Dalam: Nasir A, Muhith A, Ideputri ME. Buku Ajar: Metodologi Penelitian Kesehatan. Yogyakarta: Nuha Medika. 2011; h. 185-210.

10.Al-Saq'an R, Saify B. Urinary Tract Infections. In: Sawagroup (IRN). Pediatrics SAWA. Teheran: Sawagroup. 2006; 1-15.

11.Watson AR. Pediatric Urinary Tract Infections. EAU Update. 2004. 2; 94-100.

12.Berreman JM. Urinary Tract Infection. In: Department of Pediatrics John A. Burns School of Medicine (US). Case Based Pediatrics for Medical Students and Residents. Honolulu: University of Hawaii. 2002. p. 1-9.

13.Badan Lingkungan Hidup Provinsi Sulawesi Utara. Kondisi Lingkungan Hidup dan Kecenderungannya. Dalam: Badan Lingkungan Hidup Provinsi Sulawesi Utara. Laporan Status Lingkungan Hidup Daerah Provinsi Sulawesi Utara. Manado: Pemerintah Provinsi Sulawesi Utara. 2009; 30-46. 